\title{
PENGARUH DEWAN KOMISARIS DAN KOMITE AUDIT TERHADAP PENGUNGKAPAN CORPORATE SOCIAL RESPONSIBILITY (STUDI EMPIRIS PERUSAHAAN HIGH PROFILE DI BURSA EFEK INDONESIA)
}

\author{
Muhammad Rivandi ${ }^{1)}$ Andi Harita Putra ${ }^{2)}$ \\ 1) 2) Prodi Akuntansi, Sekolah Tinggi Ilmu Ekonomi KBP \\ ${ }^{1)}$ Email: muhammadrivandi@akbpstie.ac.id \\ ${ }^{2)}$ Email: andyhp0695@gmail.com
}

\begin{abstract}
This study aims to examine the effect of the Board of Commissioners and the Audit Committee on the Disclosure of Corporate Social Responsibility (Empirical Study on High Profile Companies on the Indonesia Stock Exchange 2013-2017). The method of data collection is done by documentation of data sourced from annual reports published through the Indonesia Stock Exchange. The sample in this study were 42 companies listed on the Indonesia Stock Exchange which were selected using purposive sampling. The analytical method used was a panel regression model. Data is tested using Eviews software version 8.0. Based on the hypothesis the test results show that the board of commissioners has no effect on disclosure of corporate social responsibility while the audit committee has a positive and significant effect on corporate social responsibility.
\end{abstract}

Keywords: Board of Commissioners, Audit Committee, Corporate Social Responsibility of dicclosure

\begin{abstract}
ABSTRAK
Penelitian ini bertujuan untuk menguji pengaruh Dewan Komisaris dan Komite Audit terhadap Pengungkapan Corporate Social resposnsibility. Perusahaan (Studi Empiris pada Perusahaan High Profile di Bursa Efek Indonesia 2013-2017). Metode pengumpulan data dilakukan dengan dokumentasi data yang bersumber dari laporan tahunan yang dipublikasikan melalui Bursa Efek Indonesia. Sampel dalam penelitian ini adalah 42 perusahaan yang terdaftar di Bursa Efek Indonesia yang dipilih menggunakan purposive sampling. Metode analisis yang digunakan adalah model regresi panel. Data diuji menggunakan perangkat lunak Eviews versi 8.0. Berdasarkan hipotesis hasil pengujian menunjukkan bahwa dewan komisaris tidak berpengaruh terhadap pengungkapan Corporate Social resposnsibility sedangkan komite audit berpengaruh positif dan signifikan terhadap tanggung jawab sosial perusahaan.
\end{abstract}

Kata kunci: Dewan Komisaris, Komite Audit, Pengungkapan Corporate Social resposnsibility 


\section{PENDAHULUAN}

Permasalahan lingkungan hidup saat ini telah menjadi suatu pokok pembicaraan di setiap kalangan masyarakat dunia. Kurang perhatiannya menjaga pelestarian lingkungan atas kegiatan operasional, baik itu dari kegiatan manusia secara individu ataupun suatu komunitas dari perusahaan-perusahaan menyebabkan berbagai kerusakan dan kerugian atas kegiatannya yang tidak mau untuk bertanggung jawab. Untuk itu perlu adanya suatu kesadaran dalam pencegahan dan pertanggungjawaban sosial dari setiap perusahaan-perusahaan agar terjaga lingkungan hidup. Bentuk aplikasi tanggung jawab yang telah dijalankan oleh perusahaan tersebut yaitu dengan adanya perlakuan atas pengungkapan tanggung jawab sosial oleh perusahaan.

Menurut Wijaya (2012) kesadaran perusahaan dalam mengungkapkan tanggung jawab sosial harus berlandaskan pemikiran bahwa selain memiliki kewajiban ekonomi dan valid pada stakeholder, perusahaan juga memiliki kewajiban kepada kelompok atau orang yang memiliki kepentingan baik didalam perusahaan ataupun diluar perusahaan. Pengungkapan CSR bertujuan sebagai sasaran evaluasi dan juga suatu alat komunikasi dengan stakeholder. Sehingga terbitlah kebijakan pemerintah nomor 47 mengenai tanggung jawab terhadap sosial serta lingkungan perseroan terbatas PP-No.47 (2012) tentang kewajiban perusahaan untuk memenuhi tanggung jawab sosial yang tidak menjadi penghalang yang menyulitkan bagi suatu perusahaan. Saat ini pengungkapan CSR sudah menjadi pencatatan yang penting pada laporan tahunan. Setiap perusahaan telah diwajibkan untuk menerbitkan laporan kegiatan CSR mereka pada laporan tahunan perusahaan, sebagai bentuk bahwa mereka telah melakukan tanggung jawab sosial berdasarkan aturan yang berlaku (PP-No.47, 2012). Undang-undang yang telah mengatur tentang CSR di Indonesia, yaitu regulasi tentang aktivitas sosial dan lingkungan perusahaan beserta laporannya yang disusun dalam Undang-undang No.40 Tahun 2007 tentang Perseroan Terbatas (UU-No.40, 2007)

Pembangunan suatu negara tidak hanya pemerintah ataupun industri saja yang bertanggung jawab, tetapi juga merupakan tanggung jawab manusia yang memiliki peran penting untuk menciptakan kenyamanan sosial dan pengendalian kualitas hidup masyarakat (Agustia, 2013). Menurut Mukti \& Kurnia (2015) Pengungkapan corporate social responsibility adalah bentuk komunikasi dari perusahaan terhadap dampak sosial dan lingkungan atas kegiatan yang dilakukan oleh perusahaan terhadap kelompok atau tokoh berkepentingan dan masyarakat umum secara keseluruhan. Bentuk penyampaian informasi di ungkapkan ke dalam laporan tahunan perusahaan, setiap kegiatan perusahaan yang berdampak akibat perusahaan maka wajib disampaikan ke dalam laporan tahunan, seperti melakukan bantuan sosial atau pemeliharaan fasilitas umum dan penanggulangan bencana. Dengan demikian, perusahaan sudah pasti melakukan tugasnya terhadap tanggung jawab sosial (Rivandi, Saleh, \& Renil, 2017).

Pengungkapan CSR di Indonesia telah mengacu pada berbagai standar pengungkapan negara-negara di seluruh penjuru dunia. Salah satunya standar pengungkapan tersebut yaitu dari Global Reporting Initiative (GRI). GRI merupakan sebuah organisasi yang membuat kerangka pelaporan keberlanjutan yang saat ini telah banyak digunakan oleh semua perusahaan di dunia untuk transparansi organisasi yang berkembang yang menyajikan pedoman pelaporan untuk menaksir dan menyampaikan kinerja ekonomi, lingkungan, dan sosial (Global-Reporting- 
Initiatif, 2012). GRI telah melakukan perkembangan dunia dalam memakai kerangka laporan berkelanjutan yang selalu berkomitmen untuk melakukan pembaruan dan penerapan di setiap negara. Standar yang berpusat terhadap Global Reporting Index (GRI) membagi indikator kinerja menjadi 3 bagian yaitu sosial, ekonomi, dan lingkungan (Global Reporting Initiative, 2013), sehingga indikator tersebut menjadi pedoman perusahaan agar mengungkapkan tanggung jawab sosialnya dengan menggunakan standar pengungkapan GRI tersebut.

Beberapa kasus tentang kerusakan lingkungan yang dilakukan oleh perusahaan terhadap masyarakat dan lingkungan sekitar perusahaan tersebut, yaitu kasus kebakaran lahan pada lokasi perladangan pohon sawit yaitu PT. Sontang Sawit Permai dan PT. WSSI pada Provinsi Riau yang terjadi pada tahun 2016. Perusahaan tersebut telah melakukan pembakaran secara liar dengan sengaja membakar lahan kosong dan telah lalai dalam melakukan pencegahan kebakaran. Kasus tersebut telah membuktikan bahwa masih ada perusahaan yang melakukan kerusakan lingkungan. Banyaknya kerugian dan permasalahan yang muncul akibat pengelolaan lingkungan yang tidak bertanggungjawab mendorong pemerintah, para pelaku dunia usaha, pecinta alam dan masyarakat untuk menerapkan pengembangan CSR. Peraturan yang telah dikeluarkan pemerintah tentang kewajiban semua perusahaan dalam melakukan pengungkapan CSR, mewajibkan perusahaan untuk bertanggung jawab dan mengungkapkan kegiatan CSR perusahaan ke dalam laporan tahunan perusahaan, dimana laporan tersebut akan menjadi bukti tertulis bahwa perusahaan telah melakukan pengungkapan CSR.

\section{TINJAUAN PUSTAKA DAN HIPOTESIS}

\section{Pengungkapan Corporate Social Responsibility}

Menurut (Rivandi et al., 2017) Corporate Social Responsibility adalah kewajiban perusahaan untuk bertanggung jawab dalam mencermati lingkungan sosial untuk kemakmuran dan kepentingan bersama. Pelaksanaan Program CSR melibatkan beberapa pihak yaitu perusahaan, pemerintah, organisasi masyarakat, perguruan tinggi, penggerak masyarakat serta kandidat penerima manfaat CSR. Untuk menjamin pelaksanaan program CSR dibutuhkan beberapa konteks yaitu : a) CSR mendapatkan kesepakatan dan dorongan dari pihak yang berperan. b) Dalam menunjang program pelaksanaan CSR ditetapkanlah pola hubungan diantara tokoh kepentingan yang jelas. c) Adanya pengelolaan program yang baik yaitu dengan menetapkan kejelasan dari tujuan program, menciptakan strategi yang akan digunakan untuk mencapai tujuan program CSR dari pihak yang berperan dalam praktik CSR (Rivandi et al., 2017).

\section{Dewan Komisaris}

Menurut Solihin (2008) Corporate Governance atau tata kelola perusahaan adalah suatu sistem yang berfungsi untuk membimbing dan mengontrol perusahaan. Sistem corporate governance memastikan pembagian hak dan kewajiban dari bermacam pihak yang memiliki tugas dalam suatu institusi seperti dewan direksi, dewan komisaris, komite audit, para manajer, stakeholder, dan tokoh kepentingan lainnya. Dewan komisaris beserta perangkatnya memiliki tanggungan kewajiban agar bisa mengawasi penerapan corporate governance yang baik, termasuk masalah implementasi tanggung jawab sosial perusahaan kepada bermacam pemangku 
kepentingan. Implementasi CSR merupakan prinsip dalam pelaksanaan corporate governance, sehingga perusahaan yang melaksanakannya sudah seharusnya menjalankan pelaksanaan CSR. Perusahaan harus menaati peraturan ataupun undang-undang dan menjalankan tanggung jawab atas masyarakat serta lingkungan agar usaha dan bisnis perusahaan dapat berjalan lama dan mendapat akreditasi menjadi good corporate citizen (Komite Nasional Kebijakan Governance, 2006).

\section{Komite Audit}

Komite audit merupakan tangan kanan dewan komisaris yang mempunyai tugas, fungsi dan tanggung jawab terhadap perusahaan, sehingga semakin mudah dalam mengendalikan dan monitoring yang dilakukan akan semakin efektif. Dikaitkan dengan pengungkapan tanggung jawab sosial, maka akan membantu dewan komisaris dan mempermudah dalam melaksanakan pengontrolan serta pengawasan atas tanggung jawab sosial (Rivandi, 2018).

Menurut Rivandi \& Gea, (2010 tanggung jawab komite audit dalam mengkaji hasil kerja dan mengembangkan hubungan kerja yang erat dengan auditor eksternal dan auditor independen. Komite audit didalam perusahaan sangat diharapkan dapat memiliki hubungan kerja dan memberdayakan internal audit atau sistem pengendalian intern perusahaan dalam melakukan ketepatan dalam penyampaian suatu laporan keuangan. Wewenang komite audit ketika mengerjakan tugas serta tanggung jawabnya didalam perusahaan yaitu melaksanakan kewenangan, tugas ataupun tanggung jawab lain yang diperintahkan dewan komisaris yang terkait erat dengan perusahaan. Setiap tugas ataupun tanggung jawab yang diberikan dewan komisaris kepada komite audit, maka komite audit wajib menjalankannya baik dari segi kinerja keuangan maupun kinerja sosial (Otoritas-Jasa-Keuangan-No.55, 2015).

\section{Pengembangan Hipotesis}

Penelitian yang dilakukan Budiman (2015), Istifaroh \& Subardjo (2017), Laksmitaningrum \& Purwanto (2013), Pradnyani \& Sisdyani (2015), Priantana \& Yustian (2011), Ratmelia (2015), Restu, Yuliandari, \& Nurbaiti (2017), Rochayatun (2016) menemukan dewan komisaris berpengaruh positif terhadap pengungkapan CSR. Pada penelitian mereka menemukan jumlah dewan komisaris cukup banyak sehingga mempengaruhi pengungkapan CSR. Semakin banyak jumlah dewan komisaris didalam perusahaan maka semakin luas pengungkapan sosial perusahaan karena kondisi manajemen yang baik dan akan semakin mudah untuk mengendalikan serta monitoring yang dilakukan semakin efektif. Selain itu juga mempermudah dalam pengambilan keputusan dan mencari kesepakatan dalam musyawarah sangat membantu dalam perkembangan perusahaan, dan akan membuat tekanan manajemen bertambah ekstensif ketika mengungkapkan tanggung jawab sosial. Maka dapat disimpulkan bahwa Semakin banyak jumlah dewan komisaris didalam perusahaan maka semakin luas pengungkapan sosial perusahaan. Berdasarkan teori dan penelitian terdahulu maka dapat diturunkan hipotesis pertama yang akan dibuktikan : 


\section{$\mathrm{H}_{1}$ : Dewan komisaris berpengaruh positif terhadap pengungkapan Corporate Social Responsibility.}

Penelitian yang dilakukan oleh Krisna \& Suhardianto (2016), Nurfadilah \& Sagara (2015), Restu et al. (2017), Rochayatun (2016), Zahra, Makhdalena, \& Trisnawati (2014) menemukan komite audit berpengaruh positif terhadap pengungkapan CSR. Komite audit melakukan pengawasannya terhadap laporan keuangan dengan baik sesuai dengan aturan yang berlaku dan bersikap jujur, sehingga komite audit dengan jumlah yang banyak mendorong pihak manajemen untuk melakukan kinerja lingkungan dan sosial, tidak hanya melaporkan keuangan saja. Semakin banyak jumlah anggota audit maka semakin baik fungsi pengawasan yang diberikan sehingga dapat melakukan evaluasi dan pengontrolan terhadap seluruh aspek kinerja perusahaan dan akan semakin mudah mengendalikan serta monitoring akan semakin efektif. Maka dapat disimpulkan bahwa semakin banyak jumlah komite audit maka semakin besar pengungkapan tanggung jawab sosial pada perusahaan. Berdasarkan teori dan penelitian terdahulu maka dapat diturunkan hipotesis kedua yang akan dibuktikan :

\section{$\mathrm{H}_{2}$ : Komite audit berpengaruh positif terhadap pengungkapan Corporate Social Responsibility.}

\section{METODE PENELITIAN Data dan Sampel}

Data yang digunakan didalam penelitian ini adalah data sekunder yaitu data yang diperoleh dari hasil publikasi yang telah dilakukan perusahaan. Sumber data diperoleh dari laporan keuangan perusahaan high profile di Bursa Efek Indonesia. Periode observasi data yang digunakan yaitu dari tahun 2013 - 2017. Pengumpulan data dan informasi penelitian menggunakan proses dokumentasi dengan mengumpulkan laporan keuangan perusahaan, atau berbagai instrumen yang berhubungan terhadap pengungkapan tanggung jawab sosial. Populasi pada penelitian adalah seluruh perusahaan high profile yang terdaftar di Bursa Efek Indonesia pada tahun 2013 - 2017, sedangkan pengambilan sampel perusahaan dengan menggunakan metode purposive sampling, Kriteria yang digunakan adalah 1) Perusahaan yang berstatus high profile yang listed di Bursa Efek Indonesia yaitu seperti : perusahaan makanan, pabrik minuman, automotive, minyak dan gas, industri pertambangan batu bara, pengolahan batu batuan, dan logam mulia, 2) Perusahaan yang telah mempublikasikan laporan tahunan (annual report), 3) Perusahaan yang tidak delisting, 4) Perusahaan yang mempunyai laba positif. Berdasarkan kriteria Purposive sampling, maka sampel perusahaan yang memenuhi kriteria penelitian sebanyak 42 perusahaan, dengan tahun pengamatan selama 5 tahun dari tahun 20132017 maka jumlah data selama periode pengamatan adalah 210 data.

\section{Tabel 1}

Kriteria Purposive Sampling Method

\begin{tabular}{clc}
\hline No & \multicolumn{1}{c}{ Kriteria } & Jumlah \\
\hline 1 & Jumlah perusahaan high profile di BEI & 125 \\
\hline 2 & $\begin{array}{l}\text { Perusahaan yang menerbitkan annual report selama periode } \\
\text { penelitian dari tahun 2013-2017 }\end{array}$ & $(42)$ \\
\hline
\end{tabular}




\begin{tabular}{clc}
\hline 3 & Perusahaan yang tidak delisting pada periode observasi & $(0)$ \\
\hline 4 & $\begin{array}{l}\text { Perusahan yang mempunyai laba positif selama periode } \\
\text { penelitian tahun 2013-2017 }\end{array}$ & $(41)$ \\
\hline & Jumlah Sampel & 42 \\
\hline Data observasi 42x5 & 210 \\
\hline
\end{tabular}

\section{Definisi Operasional Variabel}

\section{Tabel 2}

\section{Operasionalisasi Variabel Penelitian}

\begin{tabular}{|c|c|c|}
\hline Variabel & Definisi & Pengukuran \\
\hline $\begin{array}{l}\text { Pengungkapan } \\
\text { Corporate } \\
\text { Social } \\
\text { Responsibility }\end{array}$ & $\begin{array}{l}\text { Suatu bentuk komunikasi dari } \\
\text { perusahaan terhadap dampak sosial } \\
\text { dan lingkungan atas kegiatan } \\
\text { operasional yang telah dilakukan } \\
\text { oleh perusahaan terhadap } \\
\text { kelompok yang berkepentingan } \\
\text { dan masyarakat umum secara } \\
\text { keseluruhan (Mukti \& Kurnia, } \\
\text { 2015). }\end{array}$ & $\begin{array}{l}\mathrm{CSR}= \\
\frac{\text { Jumlah Pengungkapan CSR }}{\text { Total Pengungkapan GRI }} \times 100\end{array}$ \\
\hline $\begin{array}{l}\text { Dewan } \\
\text { Komisaris }\end{array}$ & $\begin{array}{l}\text { Bagian dari perusahaan yang } \\
\text { mempunyai tugas mengawasi dan } \\
\text { memberikan saran-saran kepada } \\
\text { direksi dalam pengendalian } \\
\text { perusahaan (Nugroho \& Yulianto, } \\
\text { 2015). }\end{array}$ & $\begin{array}{l}\text { DK = JDK } \\
\text { Keterangan : } \\
\text { DK = Dewan komisaris. } \\
\text { JDK = Jumlah komite audit. }\end{array}$ \\
\hline Komite Audit & 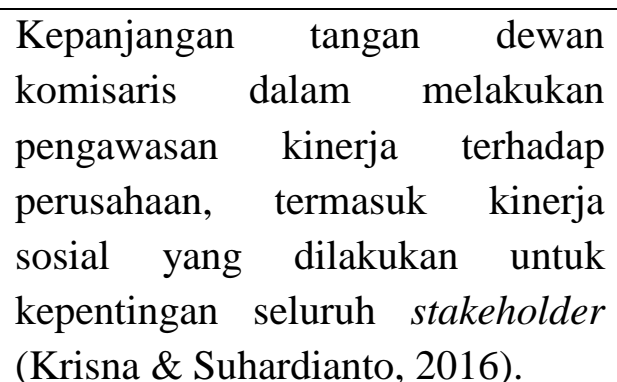 & $\begin{array}{l}\text { Keterangan : } \\
\text { KA = Komite audit. } \\
\text { JKA= Jumlah komite audit. }\end{array}$ \\
\hline
\end{tabular}

\section{Teknik Analisis Data}

Pembuktian kebenaran hipotesis maka digunakan metode analisis secara kuantitatif, dilakukan menggunakan pembentukan model pengujian kelayakan Model Regresi Panel. Menurut Winarno (2009) di dalam model regresi panel model yang dapat dipakai, yaitu Random Effect Model, Fixed Effect Model. Setiap model memiliki perbedaan didalam analisis dan hasil yang dicapai. Dimana peneliti hanya bisa memilih satu diantara model regresi panel yang akan digunakan dan untuk menentukan model regresi panel yang akan dibentuk dan dianalisis maka terlebih 
dahulu dilakukan pengujian kelayakan pada model regresi panel dengan menggunakan uji sebagai berikut:

\section{Pengujian Likelihood Ratio}

Untuk menemukan suatu masalah bahwa terdapat variabel yang tidak terlalu penting di dalam model tersebut dan bisa dilakukan dengan pengujian Likelihood Ratio (LR). Misalnya kita mempunyai model regresi sebagai berikut:

$$
\mathrm{Y}=\beta_{0}+\beta_{1} \mathrm{X}_{1}+\beta_{2} \mathrm{X}_{2}+\beta_{3} \mathrm{X}_{3}+\mu
$$

Didalam pengujian likelihood ratio sebuah model regresi dapat diterima ketika nilai probability dari F-statistik dibawah 0,05, atau seluruh variabel independen yang mendukung model regresi panel memiliki probability dibawah 0,05. Sehingga kesimpulannya adalah Ho ditolak dan Ha diterima atau pemilihan regresi panel dengan Fixed Effect Model (FEM) lebih baik untuk digunakan dibandingkan dengan model regresi panel yang lain. Begitupun sebaliknya, pengujian likelihood ratio tidak dapat diterima ketika nilai probability dari F-statistik di atas 0,05. Sehingga kesimpulannya adalah Ho diterima dan Ha ditolak atau pemilihan regresi panel dengan Fixed Effect Model (FEM) tidak baik untuk digunakan dibandingkan dengan model regresi panel yang lain.

\section{Pengujian Hausman Test}

Pengujian Hausman test telah mengembangkan uji secara umum kesalah satu spesifikasi yang dikenal dengan uji kesalahan spesifikasi regresi (Regression Spesification Error Test = RESET), (Winarno, 2009). Secara umum model pengujian Hausman test bisa dijelaskan dengan model sebagai berikut:

$$
Y_{i t}=\beta_{0}+\beta_{1} X_{1}+\beta_{2} X_{2}+\beta_{3} X_{3}+U_{i t}
$$

Didalam pengujian Hausman Test,Random Effect Model (REM) dapat diterima bila nilai $F$-probability yang dihasilkan didalam pengujian berada diatas 0,05 atau nilai F-hit < F-tabel. Sehingga kesimpulannya adalah Ho ditolak dan Ha diterima atau pemilihan regresi panel dengan Random Effect Model (REM) lebih baik untuk digunakan dibandingkan dengan model regresi panel yang lain. Didalam pengujian Random Effect Model tidak diharuskan bagi peneliti untuk menggunakan asumsi normalitas data dan gejala asumsi klasik. Begitupun sebaliknya, pengujian Hausman Test, Random Effect Model (REM) tidak dapat diterima bila nilai $F$ probability yang dihasilkan didalam pengujian berada dibawah 0,05 atau nilai F-hit kecil dibandingkan F-tabel, sehingga kesimpulannya adalah Ho diterima dan $\mathrm{Ha}$ ditolak atau pemilihan regresi panel dengan Random Effect Model (REM) tidak baik untuk digunakan dibandingkan dengan model regresi panel yang lain. Didalam pengujian Random Effect Model tidak diharuskan bagi peneliti untuk menggunakan asumsi normalitas data dan gejala asumsi klasik (Winarno, 2009). 
Tahapan dalam pengelolaan data dalam penelitian menggunakan bantuan program Eviews 8. Model penelitian yang digunakan analisis Model Regresi Panel dimana mengetahui pengaruh dewan komisaris dan komite audit terhadap pengungkapan corporate social responsibility. Model Analisis dapat dirumuskan kedalam bentuk persamaan berikut ini :

$$
\mathrm{Y}_{\mathrm{it}}=\beta_{0}+\beta_{1} \mathrm{DK}_{\mathrm{it}}+\beta_{2} \mathrm{KA}_{2 \mathrm{it}}+\mathrm{U}_{\mathrm{it}}
$$

Keterangan :

$\mathrm{Y}_{\mathrm{it}} \quad=$ Jumlah pengungkapan corporate social responsibility

$\mathrm{DK}_{1 \mathrm{it}}=$ Jumlah dewan komisaris pada tahun tertentu

$\mathrm{KA}_{2 \mathrm{i}}=$ Jumlah komite audit pada tahun tertentu

$\beta_{0} \quad=$ Konstanta bila $X=0$

$\beta=$ Koefisien regresi

$\mu_{\mathrm{it}} \quad=$ Erorr term

\section{Pengujian Hipotesis}

Pengujian hipotesis yang dilakukan menggunakan menggunakan pengujian $\mathrm{t}$ statistik dan pengujian koefisien determinasi ( $R$-Square) yaitu dengan menggunakan program Eviews 8. Koefisien determinasi ( $R$-Square) menjelaskan tentang seberapa kemampuan model dalam merangkan variabel independen (variabel bebas) berpengaruh terhadap variabel independen (variabel terikat). Koefisien variabel dependen dalam penelitian adalah dewan komisaris dan komite audit sedangkan variabel dependen adalah pengungkapan corporate social responsibility. Nilai yang dimiliki Adjusted $R$ Square yaitu antara angka 0 sampai 1. Nilai Adjusted $R$ Square dikatakan semakin besar apabila mendekati angka satu yang memperlihatkan bahwa model yang dirumuskan tersebut telah menjelaskan perubahan pengungkapan CSR (Mansuri, 2016).

Pengujian $\mathrm{t}$ statistik merupakan suatu uji statistik yang digunakan untuk melihat sejauh mana pengaruh variabel independen terhadap variabel secara parsial atau individu dimana kriteria didalam pengambilan keputusannya adalah Kriteria Pengujian adalah 1) Jika probabilitas $\leq$ alpha 0,05 maka keputusannya adalah Ho ditolak dan $\mathrm{Ha}$ diterima maka dapat disimpulkan bahwa variabel independen berpengaruh signifikan terhadap variabel dependen secara individual. 2) Jika probabilitas $\geq$ alpha 0,05 maka keputusannya adalah Ho diterima dan Ha ditolak maka dapat disimpulkan bahwa variabel independen tidak berpengaruh signifikan terhadap variabel dependen secara individual (Mansuri, 2016).

\section{HASIL DAN PEMBAHASAN}

\section{Pengujian Uji Kelayakan Model Regresi Panel}

Hausman Test

Pengujian prasyarat yang harus terpenuhi ketika peneliti menggunakan Random Effect Model adalah pengujian Hausman test. Berdasarkan hasil pengujian yang telah dilakukan diperoleh hasil sebagai berikut : 
Tabel 3

Hasil Pengujian Hausman Test

\begin{tabular}{|c|c|c|c|}
\hline Test Summary & $\begin{array}{c}\text { Chi-Sq. } \\
\text { Statistic }\end{array}$ & Chi-Sq. . $f$ & Probability \\
\hline Cross-section random & 1,2627 & 2 & 0,5319 \\
\hline
\end{tabular}

Sumber Hasil Pengolahan Data 2018

Didalam pengujian Hausman Test,Random Effect Model (REM) dapat diterima bila nilai probability cross-section random yang dihasilkan didalam pengujian berada diatas 0,05 . Sebaliknya apabila nilai probability cross-section random dibawah 0,05 maka Random Effect Model (REM) di tolak. Sesuai dengan hasil pengujian yang telah dilakukan diperoleh nilai probability sebesar 0,5319 , proses pengolahan dilakukan dengan menggunakan tingkat kesalahan sebesar 0,05. Hasil yang diperoleh didalam pengujian Husman Test menunjukkan bahwa nilai probability sebesar $0,5319 \geq$ alpha 0,05 maka dapat disimpulkan penggunaan Random Effect Model (REM) didalam model penelitian saat ini sudah tepat dan layak untuk digunakan.

\section{Regresi Random Effect Model}

Berdasarkan pengujian dalam pembentukan model maka peneliti mengambil keputusan memilih regresi Random Effect Model (REM). Peneliti melihat model regresi REM memiliki nilai probability dan nilai hubungan pengaruh variabel independen terhadap pengungkapan CSR lebih tinggi dibandingkan model regresi Fixed Effect Model (FEM), oleh karena itu peneliti memilih menggunakan pembentukan model regresi effect model di dalam model analisis regresi panel didalam penelitian.

Tabel 4

Hasil Pengujian Regresi Random Effect Model

\begin{tabular}{ccccccc}
\hline Variabel & Coefisien & t-hitung & t-tabel & Probability & Alpha & Kesimpulan \\
Kontanta & 52,638 & & & 0,00 & & \\
DK & $-0,438$ & $-1,410$ & $-1,971$ & 0,160 & 0,05 & Tidak Signifikan \\
KA & 5,515 & 4,911 & 1,971 & 0,000 & 0,05 & Signifikan \\
\hline Sumber Hasil Pengolahan Data 2018
\end{tabular}

Berdasarkan tabel 4 dapat diturunkan persamaan model analisis regresi panel adalah

$$
\mathrm{Y}_{\mathrm{it}}=52,638-0,438 \mathrm{DK}_{\mathrm{it}}+5,515 \mathrm{KA}_{2 \mathrm{it}}+\mathrm{U}_{\mathrm{it}}
$$

Pada model regresi terlihat nilai konstanta yang dihasilkan adalah sebesar 52,63847 nilai yang diperoleh tersebut mengisyaratkan bahwa jika diasumsikan tidak terjadi perubahan (peningkatan atau penurunan) dewan komisaris dan komite audit maka nilai jumlah pengungkapan CSR adalah sebesar 52,638, maka dapat 
disimpulkan tanpa keberadaan variabel dewan komisaris dan komite audit mempengaruhi jumlah pengungkapan CSR pada perusahaan high profile di Bursa Efek Indonesia yaitu relatif meningkat.

Di dalam model persamaan regresi panel juga terlihat bahwa variabel dewan komisaris memiliki nilai koefisien regresi bertanda negatif sebesar 0,4375 , maka dapat disimpulkan apabila dewan komisaris bertambah 1 orang maka pengungkapan CSR akan menurun sebesar 0,438, jika variabel independent yang lain bersifat konstan atau tetap.

Pada model regresi panel yang telah terbentuk juga teridentifikasi bahwa variabel komite audit memiliki koefisien regresi bertanda positif sebesar 5,515, maka dapat disimpulkan apabila dewan komisaris bertambah 1 orang maka pengungkapan CSR akan meningkat sebesar 5,515, jika variabel independent yang lain bersifat konstan atau tetap.

Sesuai dengan hasil pengujian hipotesis pertama dengan menggunakan variabel dewan komisaris diperoleh nilai probability sebesar 0,16. Didalam tahapan pengujian digunakan tingkat kesalahan sebesar 0,05. Hasil yang diperoleh menunjukkan bahwa nilai probability sebesar 0,16 $\geq$ alpha 0,05 maka keputusannya adalah $\mathrm{H}_{0}$ diterima $\mathrm{Ha}$ ditolak sehingga dapat disimpulkan bahwa dewan komisaris tidak berpengaruh terhadap pengungkapan CSR pada perusahaan high profile di Bursa Efek Indonesia.

Sesuai dengan hasil pengujian hipotesis kedua dengan menggunakan variabel komite audit memperoleh nilai probability dari pengujian t-statistik sebesar 0,00 . Proses pengolahan data dilakukan dengan menggunakan tingkat kesalahan sebesar 0,05 . Hasil yang diperoleh tersebut menunjukkan bahwa nilai probability sebesar $0,00 \leq$ alpha 0,05 maka keputusannya adalah $\mathrm{H}_{0}$ ditolak Ha diterima sehingga dapat disimpulkan bahwa komite audit berpengaruh positif dan signifikan terhadap pengungkapan CSR pada perusahaan high profile di Bursa Efek Indonesia.

\section{Koefisien Determinan (R-Squere $)$}

\section{Tabel 5}

Pengujian Koefisien Determinan (R-Squere $)$

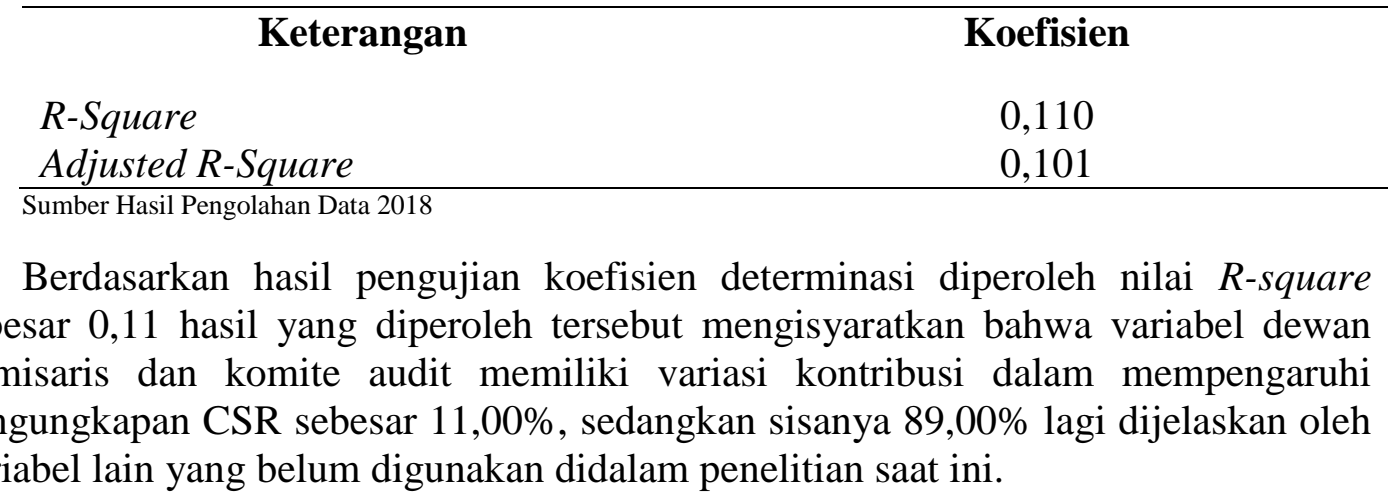




\section{Pengujian Hipotesis Dewan Komisaris Terhadap Pengungkapan Corporate Social responsibility}

Berdasarkan hasil pengujian hipotesis pertama dengan menggunakan variabel Dewan Komisaris diperoleh bahwa t-hitung lebih besar dari t tabel sebesar -1,410 $\leq$ 1,971 dengan nilai probability sebesar 0,160 . Di dalam tahapan pengujian digunakan tingkat kesalahan sebesar 0,05. Hasil yang diperoleh menunjukkan bahwa nilai tidak signifikansi sebesar $0,160 \geq$ alpha 0,05 maka keputusannya adalah $\mathrm{H}_{0}$ diterima $\mathrm{Ha}$ ditolak sehingga dapat disimpulkan bahwa dewan komisaris tidak berpengaruh terhadap pengungkapan CSR.

\section{Pengujian Hipotesis Komite Audit Terhadap Pengungkapan Corporate Social responsibility}

Pada tahapan pengujian hipotesis kedua dengan menggunakan variabel Komite Audit diperoleh hasil pengujian t-statistik bahwa t-hitung lebih besar dari t tabel sebesar 4,912>1,971 dengan nilai probability sebesar 0,000. Proses pengujian data secara statistik dilakukan dengan menggunakan tingkat kesalahan sebesar 0,05. Hasil yang diperoleh menunjukkan bahwa nilai probability sebesar $0,00 \leq$ alpha 0,05 maka keputusannya adalah $\mathrm{H}_{0}$ ditolak $\mathrm{Ha}$ diterima sehingga dapat disimpulkan bahwa komite audit berpengaruh positif dan signifikan terhadap pengungkapan CSR.

\section{PEMBAHASAN}

\section{Pengaruh Dewan Komisaris Terhadap Pengungkapan Corporate Social Responsibility}

Berdasarkan hasil pengujian hipotesis pertama ditemukan bahwa dewan komisaris tidak berpengaruh terhadap pengungkapan CSR pada perusahaan high profile di Bursa Efek Indonesia. Hasil uji menjelaskan sesuai dengan hasil penelitian yang ditemukan oleh Dermawan \& Deitiana (2014), Krisna \& Suhardianto (2016), Nugroho \& Yulianto (2015) dan Nurfadilah \& Sagara (2015) menemukan dewan komisaris tidak berpengaruh terhadap pengungkapan CSR. Hal tersebut terjadi karena intervensi yang diberikan oleh dewan komisaris pada pihak manajemen atas kinerja sosial perusahaan tidak terlalu tampak dan lebih menjalankan fungsinya sebagai pengawas pada kinerja keuangan dari pada sosial.

Tugas dewan komisaris menurut Dermawan \& Deitiana (2014) adalah melakukan pelaksanaan pengawasan untuk mengendalikan perusahaan yang dikerjakan oleh kelompok manajemen perusahaan. Sebagai wakil shareholder dewan komisaris akan membuat kebijakan menggunakan laba perusahaan untuk aktivitas operasional perusahaan yang lebih menguntungkan daripada melakukan aktivitas sosial sehingga dewan komisaris mengabaikan dalam pengungkapan tanggung jawab sosial perusahaan. Besar kecilnya jumlah dewan komisaris dalam perusahaan belum dapat dikatakan efektif sebagai pengawas dan pemberi rekomendasi agar manajemen menjalankan aktivitas sesuai dengan apa yang diinginkan para stakeholder terkait aspek sosial dan lingkungan.

Apabila dewan komisaris berjumlah kecil maka perusahaan akan melakukan pengungkapan CSR yang lebih baik dibandingkan dengan dewan komisaris yang berjumlah besar. Alasan yang bisa menjelaskan dikarenakan dewan komisaris yang berjumlah kecil akan memiliki efektivitas yang baik terhadap pengawasan manajemen perusahaan. Selain itu, dewan komisaris yang berjumlah besar juga menjadi kurang efektif karena dominasi anggota dewan komisaris yang 
mementingkan kepentingan pribadi atau kelompoknya sehingga mengesampingkan kepentingan perusahaan. Oleh karena itu, seharusnya pembentukan dewan komisaris harus memperhatikan jumlah, kemampuan, dan integritas anggota sehingga dapat melakukan fungsi pengawasan, pengendalian dan memberikan arahan yang baik demi kepentingan perusahaan.

\section{Pengaruh Komite Audit Terhadap Pengungkapan Corporate Social Responsibility}

Berdasarkan hasil pengujian hipotesis kedua ditemukan bahwa komite audit berpengaruh positif dan signifikan terhadap pengungkapan CSR pada perusahaan high profile di Bursa Efek Indonesia. Hasil penelitian ini sesuai dengan penelitian yang dilakukan Krisna \& Suhardianto (2016), Nurfadilah \& Sagara (2015), Restu et al. (2017), Rochayatun (2016), Zahra, Makhdalena, \& Trisnawati (2014) bahwa komite audit berpengaruh positif terhadap pengungkapan CSR. Hal tersebut terjadi karena komite audit memberikan pengaruh yang lebih besar dibandingkan dewan komisaris terhadap luas pengungkapan tanggung jawab sosial. Perusahaan meningkatkan pengawasannya terhadap kegiatan sosial dengan meningkatkan jumlah komite audit. Keberadaan komite audit dapat membantu dewan komisaris dalam pengawasan kinerja perusahaan, baik dari segi internal ataupun eksternal.

Secara teori yang dijelaskan bahwa Semakin banyak jumlah komite audit, maka semakin baik fungsi pengawasan yang diberikan sehingga kegiatan sosial berjalan dengan lancar dan legitimasi dapat terjaga Krisna \& Suhardianto (2016). Berdasarkan teori hasil penelitian dapat di interpretasikan bahwa semakin besar jumlah komite audit pada perusahaan high profile maka semakin besar perusahaan dalam mengungkapkan CSR pada perusahaan high profile..

Semakin banyak jumlah komite audit, maka semakin baik fungsi pengawasan yang diberikan sehingga kegiatan sosial berjalan dengan lancar dan legitimasi dapat terjaga. Komite audit mempunyai peran yang sangat penting dan strategis dalam hal memelihara kredibilitas proses penyusunan laporan keuangan seperti halnya menjaga terciptanya sistem pengawasan perusahaan yang memadai termasuk pengawasan terhadap lingkungan sosial sehingga pengungkapan CSR akan dapat dilakukan dengan baik pada perusahaan high profile di BEI.

\section{PENUTUP}

\section{Kesimpulan}

Berdasarkan hasil dari pengujian hipotesis maka dapat disimpulkan bahwa dewan komisaris tidak berpengaruh terhadap pengungkapan corporate social responbility dan komite audit berpengaruh positif signifikan terhadap pengungkapan corporate social responbility.

Saran

Peneliti menyadari bahwa hasil penelitian yang diperoleh didalam penelitian ini masih memiliki sejumlah kelemahan yang disebabkan oleh adanya keterbatasan yang peneliti miliki yaitu 1) Jumlah data observasi yang digunakan hanya lima tahun, untuk penelitian periode observasi dalam tempo waktu lima tahun digolongkan pendek sehingga mengakibatkan hasil yang diperoleh juga bermanfaat untuk waktu yang relatif pendek. 2) Komposisi data yang digunakan didalam penelitian juga tidak begitu beragam, dimana masih terdapat sejumlah data yang digolongkan outlier sehingga berakibat pada hasil penelitian yang diperoleh. 3) Masih terdapatnya 
sejumlah variabel yang juga mempengaruhi pengungkapan CSR yang tidak digunakan didalam penelitian ini seperti posisi likuiditas perusahaan, corporate governance, dan berbagai variabel lainnya.

\section{REFERENCE}

Agustia, D. (2013). Pengaruh Struktur Kepemilikan Dan Dewan Komisaris Terhadap Corporate Social Responsibility Dan Reaksi Pasar. EKUITAS: Jurnal Ekonomi Dan Keuangan, 17(3), 376-390. https://doi.org/10.24034/j25485024.y2013.v17.i3.2258

Budiman, N. A. (2015). Faktor-faktor Yang Mempengaruhi Pengungkapan Tanggung Jawab Sosial Perusahaan. Jurnal Riset Akuntansi Mercu Buana, 1(1), $14-34$.

Dermawan, D., \& Deitiana, T. (2014). Faktor-Faktor Yang Mempengaruhi Pengungkapan Corporate Social Responsibility. Jurnal Bisnis Dan Akuntansi, 16(2).

Erwanti, Y., \& Haryanto. (2017). Pengaruh Ukuran Perusahaan, Profitabilitas, Dewan Komisaris, Komite Audit, Dan Kualitas Audit Terhadap Pengungkapan Informasi Pertanggungjawaban Sosial. Journal Of Accounting, 6, 1-14.

Global Reporting Initiative. (2013). Pedoman Pelaporan Keberlanjutan G4: prinsipprinsip pelaporan dan pengungkapan standar. In Global Reporting Initiative. Global Reporting Initiative.

Global-Reporting-Initiatif. (2012). GRI Occupational Health And Safety Working Group Terms Of Reference. Global Reporting Initiative.

Istifaroh, A., \& Subardjo, A. (2017). Faktor-Faktor Yang Mempengaruhi Corporate Social Responsibility. Jurnal Ilmu Dan Riset Akuntansi, 6(6).

Komite Nasional Kebijakan Governance. (2006). Pedoman Umum Good Corporate Governance Indonesia. In Pedoman Umum Good Corporate Governance Indonesia. Retrieved from www.governance-indonesia.or.id

Krisna, A. D., \& Suhardianto, N. (2016). Faktor-Faktor Yang Mempengaruhi Pengungkapan Tanggung Jawab Sosial. Jurnal Akuntansi Dan Keuangan, 18(2), 119-127. https://doi.org/10.9744/jak.18.2.119-128

Laksmitaningrum, C. F., \& Purwanto, A. (2013). Analisis Pengaruh Karakteristik Perusahaan, Ukuran Dewan Komisaris Dan Struktur Kepemilikan Terhadap Pengungkapan CSR ( Studi Empiris Pada Perusahaan Manufaktur Yang Terdaftar Di Bursa Efek Indonesia Tahun 2009-2011 ). Journal Of Accounting, 2(3), 1.

Mansuri. (2016). Modul Praktikum Eviews Analisis Regresi Linier Berganda Menggunakan Eviews.

Mukti, A., \& Kurnia. (2015). Pengaruh Karakteristik Perusahaan Dan Ukuran Dewan Komisaris Terhadap Pengungkapan Corporate Social Responsibility. Jurnal Ilmu Dan Riset Akuntansi, 4(12).

Nugroho, M. N., \& Yulianto, A. (2015). Pengaruh Profitabilitas Dan Mekanisme Corporate Governance Terhadap Pengungkapan Csr Perusahaan Terdaftar JII 2011-2013. Accounting Analysis Journal, 4(1), 1-12. https://doi.org/http://doi.org/10.15294/aaj.v4i1.7829

Nurfadilah, W., \& Sagara, Y. (2015). Pengaruh Good Corporate Governance , Karakteristik Perusahaan Dan Regulasi Pemerintah Terhadap Pengungkapan Corporate Social Responsibility. Akuntabilitas, VIII(1), 78-89. https://doi.org/10.15408/akt.v8i1.2763 
Otoritas-Jasa-Keuangan-No.55. (2015). Pembentukan dan Pedoman Pelaksanaan Kerja Komite Audit (Vol. 1998). Vol. 1998. Jakarta: Otoritas Jasa Keuangan Republik Indonesia.

PP-No.47. (2012). Tanggung Jawab Sosial Dan Lingkungan Perseroan Terbatas. Retrieved from http://www.kemendagri.go.id/media/documents/2012/05/21/p/p/pp_no.472012.pdf

Pradnyani, I. G. A. A., \& Sisdyani, E. A. (2015). Pengaruh Ukuran Perusahaan, Profitabilitas, Leverage, Dan Ukuran Dewan Komisaris Pada Pengungkapan Tanggung Jawab Sosial Perusahaan. E-Jurnal Akuntansi Universitas Udayana, 2(11), 384-397.

Priantana, R. D., \& Yustian, A. (2011). Pengaruh Struktur Good Corporate Governance Terhadap Pengungkapan Corporate Social Responsibility Pada Perusahaan Keuangan Yang Terdaftar Di Bursa Efek Indonesia. Jurnal Telaah Dan Riset Akuntansi, 4(1).

Ratmelia, Y. (2015). Pengaruh Kepemilikan Sahan Publik, Ukuran Dewan Komisaris, Profitabilitas , Dan Umur Perusahaan Empiris Pada Perusahaan Real Estate And Property Yang Terdaftar Di Bei Pada Tahun 2012-2015 ). Jurnal Ekonomi Dan Bisnis Universitas Dian Nuswantoro Semarang, 1-15.

Restu, M., Yuliandari, willy sri, \& Nurbaiti, A. (2017). Pengaruh Ukuran Dewan Komisaris, Proporsi Dewan Komisaris Independen dan Ukuran Komite Audit Terhadap Pengungkapan Corporate Social Responsibility (studi kasus pada perusahaan BUMN yang terdaftar di Bursa Efek Indonesia periode 2013-2016). Jurnal Ekonomi Dan Bisnis, 4(3), 2742-2749.

Rivandi, M. (2018). Pengaruh Enterprise Risk Management Disclosure Dan Corporate Governance Terhadap Nilai Perusahaan. Jurnal Benefita, 3(2), 137. https://doi.org/10.22216/benefita.v3i2.3113

Rivandi, M., \& Gea, M. M. (2018). Pengaruh Mekanisme Corporate Governance Terhadap Ketepatan Waktu Pelaporan Keuangan: Studi pada Perusahaan Manufaktur di BEI. Jurnal Akuntansi Dan Pajak, 19(1), 1-154. https://doi.org/10.29040/jap.v19i1.167

Rivandi, Saleh, M., \& Renil. (2017). Leverage, Profitabilitas, Ukuran Perusahaan, Pengungkapan Corporate Social Responsibility Dengan Pendekatan Kausalitas. Jurnal Pundi, 1(1), 11-22.

Rochayatun, S. (2016). Faktor-faktor Yang Mempengaruhi Corporate Social Responsibility Disclosure (CSRD). Jurnal Penelitian Ilmu Ekonomi Wiga, 6(1), 63-79.

Solihin, I. (2008). Corporate Social Responsibility.

UU-No.40. (2007). Perseroan Terbatas. Undang-Undang Republik Indonesia Nomor 40 Tahun 2007 Tentang Perseroan Terbatas. Jakarta: Republik Indonesia.

Wijaya, M. (2012). Faktor-Faktor Yang Mempengaruhi Pengungkapan Tanggungjawab Sosial Pada Perusahaan Manufaktur Yang Terdaftar Di Bursa Efek Indonesia. Jurnal Ilmiah Mahasiswa Akuntansi, 1(1), 26-30.

Winarno, W. (2009). Operasional Eviews. Jakarta: Salemba Empat.

Zahra, S. F., Makhdalena, \& Trisnawati, F. (2014). Pengaruh Komisaris Independen Dan Komite Audit Terhadap Pengungkapan Corporate Social Responsibility Perusahaan Pertambangan Di Bursa Efek Indonesia Periode 2012 - 2014. Jurnal Fakultas Keguruan Dan Ilmu Pendidikan Universitas Riau, 1-11. 